\title{
HUMANS, NONHUMAN OTHERS, MATTER AND LANGUAGE: A DISCUSSION FROM POSTHUMANIST AND DECOLONIAL PERSPECTIVES'
}

\section{HUMANOS/AS, OUTROS/AS NÃO-HUMANOS/AS, MATÉRIA E LIINGUA/LINGUAGEM: UMA DISCUSSÃO A PARTIR DE PERSPECTIVAS PÓS-HUMANISTAS E DECOLONIAIS}

\section{Laryssa Paulino de Queiroz Sousa* Rosane Rocha Pessoa**}

\begin{abstract}
Our objective is to discuss decolonial and, mainly, posthumanist perspectives, as we engage in an inter-epistemic dialogue, which encompasses discussions on matter and language. At first, we address Indigenous thoughts in order to relate them to decolonial and posthumanist worldviews, briefly concentrating our attention on some arguments concerning their relation, and we justify our choices. We draw on critiques of colonial and humanist ideas about humans, nonhuman others and matter, and we then discuss traditional conceptions of language From a posthumanist framework, we approach understandings of language that directly intertwine it with materiality. Based on the problematizations we present, our aim is to expand understandings of what it means to be buman and perceptions of language, as we become involved in a project that seeks to see and go beyond human hubris. Therefore, we encourage an onto-epistemological review of language, based on its entanglement with matter.
\end{abstract}

Keywords: Posthumanism; decoloniality; matter and language.

\section{RESUMO}

Nosso objetivo é discutir perspectivas decoloniais e, principalmente, pós-humanistas, conforme nos engajamos em um diálogo interepistêmico, que engloba discussões sobre a matéria e a língua/linguagem. Em um primeiro momento, abordamos pensamentos indígenas de forma a relacioná-los com visões de mundo decoloniais e pós-humanistas, brevemente focando em alguns argumentos concernentes a essa relação e justificamos nossas escolhas. Partimos de críticas das ideias coloniais e humanistas sobre os seres humanos, os/as outros/ as não-humanos/as e sobre a matéria, e então discutimos concepções tradicionais de língua. A partir de um quadro pós-humanista, abordamos entendimentos sobre língua/linguagem que diretamente se entrelaçam com a materialidade. Com base nas problematizações

\footnotetext{
* Universidade Federal de Goiás (UFG), Goiânia, GO, Brasil. laryssa.paulino1@gmail.com, https:// orcid.org/0000-0001-6790-5611

** Universidade Federal de Goiás (UFG), Goiânia, GO, Brasil. Bolsista de Produtividade em Pesquisa (CNPq).pessoarosane@gmail.com.

1. Thanks to the Coordenação de Aperfeiçoamento de Pessoal de Nivel Superior (CAPES) for its financial support in order to develop this study.
} 
que apresentamos, nossa intenção é ampliar a compreensão do que significa ser bumano/a e percepções de língua/linguagem, ao passo que nos envolvemos em um projeto que busca enxergar e ir além da arrogância humana. Portanto, encorajamos uma revisão ontoepistemológica da língua, com base em seu emaranhamento com a matéria.

Palavras-chave: Pós-humanismo; decolonialidade; matéria e linguagem/língua.

\section{PREAMBLE}

We have already been working with decolonial thoughts (BORELLI $I_{i}$ PESSOA, 2019; MASTRELLA-DE-ANDRADE; PESSOA, 2019; PESSOA, 2019; PESSOA BORELLI; SILVESTRE，2018; PESSOA; SILVESTRE; BORELLI，2019) and posthumanist perspectives (SOUSA, 2017, 2018, 2019a, 2019b, 2019c) for about three years. However, in this paper, our objective is to discuss both praxiologies ${ }^{2}$ together, with a special focus on matter and language. By decoloniality, we mean the movements towards delinking ourselves from the modes of living, thinking and being (MIGNOLO, 2007) that were built as a result of the process of colonization and have been maintained even after the end of colonialism in the form of, for example, racial, class, sexual, gender, linguistic, spiritual and epistemic hierarchies, which characterize our Eurocentrist world-system (GROSFOGUEL, 2010). Concerning posthumanism, we understand it is a project that questions what it means to be human, as it engages with ethico-onto-epistemological (BARAD, 2003, 2007) challenges that arise in contemporary times, since there is a constant attempt to consider and address human and nonhuman entities, language, and space from a flat hierarchy perspective. Posthumanism is thereby connected to critical projects that seek social justice, but it is committed to the search for a kind of justice that goes beyond it.

Like Patel (2016), Papadopoulos (2018) and Pennycook (2018b, 2019), we perceive posthumanism and decoloniality as closely related and we believe they can greatly benefit from each other. These are two perspectives that have been important for the development of our work, especially concerning language education and teacher education. Therefore, from our viewpoint, they are deeply connected in face of the objectives we pursue and challenges we meet in our work.

Aswe seeit, one of the aspects posthumanismand decoloniality havein common is that they are both partly influenced by Indigenous knowledges ${ }^{3}$. Nascimento

2. We use the term praxiology to address both theory and practice, which we perceive as integrated and inseparable.

3. When we mention Indigenous knowledges in this paper, by no means do we intend to present an essentializing and totalizing view of them, nor do we claim to appropriate them. Instead, we refer to them because we think that their influence upon decolonial and posthumanist perspectives must be rightfully recognized. 
(2017) shows how Indigenous peoples perceive the world in a nondichotomous way when it comes to interactions between humans and nonhumans, mind and spirit, what is tangible and what is intangible, and between these entities and language. As they engage with nature ${ }^{4}$ in a holistic and interdependent way, their production of knowledge and perceptions are relational and shared with the earth, animals, and plants, without hierarchies between them and people being established ${ }_{i}$ thus, in this perspective, all materiality (alongside spirituality) plays a role in the processes we experience (NASCIMENTO, 2017; PATEL, 2016). According to Patel (2016) and Nascimento (2017), such understanding is closely related to decolonial thoughts, and we add, to posthumanist perspectives as well, as it decenters human beings in the big picture. Indigenous peoples have perceived life and the world without the dualisms and binarisms that the modern/colonial and humanist world has imposed since long before decolonial and posthumanist praxiologies emerged.

Nonetheless, as Pennycook (2018b, p. 141) underscores, in relation to posthumanism, "[t]he West with its talk of the Anthropocene is rediscovering Indigenous knowledges and, as has long been part of that history, claiming them for itself." He emphasizes that, in a way, posthumanism has an interest in prehumanism, "[...] in thinking before the great rise of Western thought and destruction, in turning to alternative ways of thinking about the world and our relationship to it" (PENNYCOOK, 2018b, p. 141). For the author, Indigenous knowledges can help us rethink the divisions colonialism, its progeny coloniality and humanism have created between humans and nonhumans. In the same perspective, Martin and Mirraboopa (2003) and Patel (2016) state that Indigenous ways of knowing, being and doing can teach us a lot about our relationship with others and the planet.

We are aware that some decolonial scholars, like Mignolo and Vázquez (2017) and Mignolo (2018a, 2018b), do not think these frameworks are/should be related, let alone that we should engage in a dialogue with them, due to their historical, political, epistemological, and even ontological dissimilarities. For instance, due to the fact that the posthumanist project started in Europe, these authors automatically reject any reflection and contribution coming from this movement, as they seem to understand it as a continuation of humanism. In addition, when they briefly address posthumanism in their works, they overgeneralize it, as if it were a homogenous perspective, although posthumanism is an umbrella term used "to refer to a variety of movements and schools of thought" (FERRANDO, 2013, p. 26), and as Pennycook

4. Although we are aware that nature and culture are western inventions, that is, ontological fictions, insofar as "Indigenous peoples do not make this distinction" (MIGNOLO, 2018b, p. 159), we use the term nature here to refer to life in general. 
(2018a, p. 445) argues, "a fairly broad and, at times, chaotic field." Likewise, they also overgeneralize ideas about Europe and the research that has currently been developed there. Kerner (2018, p. 41, emphasis in original) claims that

\begin{abstract}
Western epistemology, [...] in Mignolo [(2018b)], appears as a homogenous black box, a box in which everything works according to the same logic of rationality and universalism. To me, this conception seems questionable - for two reasons. First, it neither acknowledges those currents within Western thought that conceptualize modernity as dialectic or ambivalent - like for instance first generation Frankfurt School critical theory or poststructuralism - nor those currents within Western thought that precisely criticize any favoring of individualism and individualist rationalism; examples for the latter range from feminist care ethics (e.g. Gilligan, 1982, Larrabee, 1993) via positions in the field of post-humanism (e.g. Braidotti, 2013; Haraway, 2016) to the convivialist manifesto (Les Convivialistes, 2014).
\end{abstract}

In spite of the complexity of western epistemology, for Mignolo (2018b), the production of knowledge that comes from Europe cannot hold dialogue with his decolonial project. Furthermore, Vázquez (in conversation with MIGNOLO, 2017 , p. 505-506, our translation, quotation marks in original) affirms that

[...] the problem with the 'posthuman' is that it loses sight of relationality, it becomes a projection of human life mediated through communication technologies and biotechnology. [...] While the thought of the 'posthuman' points to the future of life mediated by digital and genetic technologies, decoloniality points to the liberation of life forms that were eradicated or, at best, denigrated by the great project of 'humanity' of modernity/coloniality. ${ }^{5}$

Vázquez's contention is very simplistic and reductionist. It seems that the author disregards the difference between transhumanism and posthumanism. Transhumanism has as its focus "possible biological and technological evolutions", and is rooted in humanist understandings (FERRANDO, 2013, p. 27), while posthumanism is fully engaged with "a critical and historical account of the human" (FERRANDO, 2013, p. 28), grounded on social critiques. Posthumanism does seek to grasp the relations between humans and technology (understood in a broader sense as any object used to achieve a purpose), but it does it in order to understand the ontological significance of technology, being that only one of posthumanism's research interests. Unlike what Vázquez (in conversation with MIGNOLO, 2017) states, decolonial and posthumanist projects have similar agendas (PENNYCOOK, 2019), depending on the locus of enunciation of the ones involved in such projects.

5. "[...] el problema con el 'poshumano' es que pierde de vista la relacionalidad, se convierte en una proyección de la vida humana mediada a través de las tecnologías de comunicación y de la biotecnología. [...] Mientras el pensamiento de lo 'poshumano' apunta al futuro de la vida mediada por las tecnologías digitales y genéticas, la decolonialidad apunta a la liberación de las formas de vida que fueron erradicadas $\mathrm{o}$, en el mejor de los casos, denigradas por el gran proyecto de 'humanidad' de la modernidad/colonialidade." 
As opposed to Mignolo's (2018a) argument that posthumanism asserts universality, we perceive posthumanism, like Pennycook (2019), as a localized viewpoint, of which the focus is on understanding the relations between humans, nonhuman others, matter, language, and space in one's own context. In addition, Mignolo's (2018a) critique ignores a multiplicity of places and people, some outside Europe, who are also part of the movement.

In relation to the discussion held here, we highlight that when we mention posthumanist and decolonial perspectives, by no means do we intend to generalize them, as if they were unitary movements; and, second, we underscore that our purpose is to draw on our readings and understandings of both praxiologies, which are evidently based on our own locus of enunciation, in an attempt to encourage knowledge expansion. We rely on the idea that scholars whose work is grounded on ethics and justice should be open to listen to one another, for they all might have something to contribute in order to expand our worldviews. As Nascimento (2017) points out, recognizing other perspectives is a necessary condition for the creation of new epistemologies. In the same vein, Pennycook (2018b, p. 131) affirms that the broad scope of posthumanism draws on "multiple related areas without being reduced to them."

According to Winnubst (2018), despite their differences, both decolonial and posthumanist frameworks aim to deconstruct the idea of buman created by modern/ colonial and humanist perspectives. Moreover, concerning their similarities, we understand that both decoloniality and posthumanism see everything as integrated, incorporated, that is, human and nonhuman entities as affecting and being affected by each other. Regarding posthumanism, what it brings to the table is its ethico-onto-epistemological perspective (BARAD, 2003, 2007), meaning that ethics, knowing and being are perceived as intertwined. This framework not only deconstructs what we understand by buman, but it also encompasses all nonhuman others in its scope in a nonhierarchical way. Similarly, for Patel $(2016$, p. 7), who is a decolonial scholar, there is a need to "[s]hift material relations among human beings, including their connections to land (land here meaning land, air, water, and space) and other beings." Accordingly, in Papadopoulos's words (2018, p. 205), "[s]ocial movements start to become more than social, movements of matter and the social simultaneously, movements that change power by creating alternative forms of life."

Based on our experience in applied linguistics, we see the importance of decolonizing ourselves, that is, of unlearning modern/colonial and humanist structures which have shaped us (as buman beings and as teachers/professors), our 
understandings of language, and our views of language teaching and learning, as well as of teacher education. Such attitude has the potential to foment new ways, new possibilities of dealing with what we do and with who we become.

Here, we endorse an onto-epistemological review of language, based on its entanglement with matter. Our objective is to encourage reflection on what language is (or, in more posthumanist terms, on what it becomes) and new ways of understanding language and communication. In order to do that, we rely on interepistemic dialogues (NASCIMENTO, 2017) between decolonial and, mainly, posthumanist perspectives, with the aim of offering one possible way forward to think about language and the elements and processes it involves. Following Deleuze and Guattari's suggestion (2005), as we draw on decolonial and posthumanist scholarship here, we choose to take an attitude of and, and, and, rather than instead, so as to try to explore other possibilities for understanding, especially, language and materiality, and their relation.

This paper is divided into five parts. In this first section, we address some general aspects, as we justify our choices for this discussion. In the second section, we provide some critiques of colonial and humanist perspectives regarding understandings of humans, nonhuman others and matter. In the third section, we reflect on traditional conceptions of language. In the fourth section, we discuss language from a posthumanist viewpoint. Finally, we present some final remarks.

\section{DECOLONIAL AND POSTHUMANIST CRITIQUES: HUMANS, NONHUMAN OTHERS AND MATTER}

Colonial and humanist perspectives are firmly embedded in modern epistemologies, which emerged from European contexts. Their ideals were (and still are) exclusionary, as, throughout history, the ones considered fully buman were Western, white, male, heterosexual, able-bodied and upper-class individuals only; that is, these two frames of reference are eminently hierarchical. Consequently, for a long time in our history, those who did not fit into the predetermined buman category were considered less than human, sometimes were compared to animals, and, on some occasions, were even regarded as lesser beings than nonhuman others, on grounds of race, class, gender, sexual orientation, disability etc. (COOK, 2016; FERRANDO, 2013; MIGNOLO, 2000, 2018b; PENNYCOOK, 2018a, 2018b, 2019; PRATT, 2012; QUIJANO, 2005; SOUSA, 2018, 2019b, 2019c; VERONELLI, 2015, 2019). 
At another historical moment, with the French Revolution and the Enlightenment, as Pennycook (2018b, p. 76) argues, humanist universalism sought "to bring all humans into the same framework." By directly and indirectly setting an archetype of the human subject (whose characteristics were mentioned in the previous paragraph), based on homogeneity, essentialization and generalizations, humanism promoted ideas of superiority and inferiority among humans, which are elements that contributed to disregarding human differences and, consequently, the inequalities and injustices experienced by minoritized groups throughout history.

Consequently, those considered less human, or even not human at all, also had their forms of communication denied as languages (QUIJANO, 2000; VERONELLI, 2015, 2019). As Veronelli (2015, p. 113) asserts, "[t]o find in colonized peoples the ability to express complex cosmological, social, scientific, erotic, economic meaning is at odds with their reduction to inferior, animal-like beings." Therefore, from this viewpoint, even if colonized people acquired/learned a European language, they could not evolve in the human scale, insofar as they would never be considered legitimate speakers with the same intellectual capacity as Europeans (NASCIMENTO, 2019; VERONELLI, 2015, 2019). Accordingly, the ideas behind the concepts of bumanity and language, as traditionally understood, have always referred to particular subjects, with particular bodies and behaviors. Traces of these colonial ideas persist nowadays, if we consider the case of the native speaker episteme, for instance, which is grounded on notions such as that of the nonnative speaker as a deficient speaker. This colonial project occurs through ontological and epistemological processes, which create intertwined colonial discourses about Others.

In addition, since then, and mainly in recent modern times, arguments have been presented to make human beings be perceived as the only ones able to do certain things. Modern history thereby has been constructed on the grounds of an anthropocentric way of understanding the world, based on human exceptionalism, which emphasizes the superiority of humans over others. Inspired by Santos's (2010) and Fabrício's (2017) discussions on coloniality and decoloniality, we argue that we need to unthink humanist perspectives concerning humans, nonhuman others, space, and language, in order to be able to think about them in posthumanist terms. Both authors criticize the dichotomous logic that creates practices of division and classification of things, people, and phenomena, which lead to a binary perception of the world, without the consideration of their nuances, imprisoning them in totalizing and essentializing categorizations. 
The decolonial and posthumanist frameworks do not simply engage in the rejection and deconstruction of post-dualistic and post-hierarchical forms of thought, but they rather seek to know them, to research and recognize their concrete effects, and to invest in the development of new possibilities (BRAIDOTTI, 2016; FABRÍCIO, 2017; FERRANDO, 2013; MALDONADOTORRES, 2007; MURRIS, 2016; PATEL, 2016; SOUSA, 2018; TOOHEY, 2018a; VERONELLI, 2015, 2019). In addition, in this line of thought, as an ethical commitment, the posthumanist perspective aims at including all those who have suffered along the construction of humanism - people, animals, objects, spaces, and the planet as a whole (APPLEBY; PENNYCOOK, 2017; BRAIDOTTI, 2013, 2016, 2017; COOK, 2016; HARAWAY, 2008; LATOUR, 2004; PENNYCOOK, 2018a, 2018b). As Deleuze and Guattari (2005), Pennycook (2018a, 2018b, 2019), Appleby and Pennycook (2017) and Toohey (2018a, 2018b) affirm, in order to go beyond anthropocentrism, it is necessary to decenter humans, and to consider things, discourses and people as materially entangled, as entities implicated and embedded in assemblages instead.

According to Deleuze and Guattari (2005, as cited in TOOHEY, 2018b, p. 3 ), assemblage is the entanglement of entities, that is, in accordance with the ontology proposed by them: "things are as they are (while also constantly changing) because of their interrelations and their entanglements with other things (which are also in other assemblages that are constantly changing)." This view is in keeping with the idea of vincularidad held by some Andean Indigenous thinkers, which, for Walsh and Mignolo $(2018$, p. 1), "[...] is the awareness of the integral relation and interdependence amongst all living organisms (in which humans are only a part) with territory and land and the cosmos." For Coole and Frost (2010), De Freitas and Curinga (2015) and Toohey (2018a, 2018b), people, animals, objects, nature, discourse, and so on, are always becoming together in relation to and with one another. This ontological perspective focuses on processes of becoming rather than being.

For Barad $(2003,2007)$, as we are always entangled with other entities, we experience ongoing processes of intra-action. Based on Barad's arguments (2011), Toohey (2018a, p. 34, emphasis added) explains that

Barad's intra-action contrasts with (or builds from) the idea of interaction. She argued that, if two things are in interaction, then they are separate entities with individual characteristics, but if they are what they are in relation to one another, they intra-act and come into being (on their way to becoming something else) through their entanglement.

As Coole and Frost (2010) claim, our everyday life is surrounded and immersed in matter, and we ourselves are composed of it. Accordingly, Bennett 
(2010) advocates for the need to raise the status of materiality. For Barad (2003, 2007), Coole and Frost (2010), Ferrando (2013) and De Freitas and Curinga (2015), matter should not be perceived as fixed, stable, passive, inert and immutable, but as something that has active participation in the world, as something that has agency (which is understood as distributed). As Pennycook (2019) argues, we need to be able to see that nonhuman others, like objects, play a very big role in relationship to the human. These entities have affordances, that is, specific physical and nonphysical characteristics that invoke ideas, feelings etc., and we thereby act in specific ways also because of them. Moreover, according to Barad (2007, p. 136), posthumanist thought deconstructs the notion of "[...] the body as the natural and fixed dividing line between interiority and exteriority"; in a way, boundaries between inside and outside are softened. We will return to these perspectives, relating them to language, in the following sections.

\section{A REFLECTION ON TRADITIONAL CONCEPTIONS OF LANGUAGE}

Although contemporary movements, characterized as critical, have influenced and even changed conceptions in the field of applied linguistics, premises and assumptions grounded on modern/colonial and humanist perspectives still strongly permeate the studies carried out in the area. It is possible to notice how processes of dichotomization, essentialization, totalization, universalism, reductionism and homogenization are still clearly present in applied linguistics (SEVERO, 2017; SOUSA, 2017, 2018, 2019b, 2019c). Severo (2017, p. 40, our translation) inquires

[...] about the relation between the emergence of linguistics as a field of scholarship (FOUCAULT, 1979, 2000) and the colonial project, in which language has been transformed into an object to be scrutinized, classified, named, riven, analyzed and described according to certain rules that define what counts as true within the limits of a given discursive regime. ${ }^{6}$

Based on Foucault (1979, 2008), Severo explains that such discursive regimes are not atemporal but are rather conditioned by specific historical and socio-political conditions, and that, therefore, languages are invented by these same regimes. From that perspective, laws and rules were upheld for all languages, as well as specific ways of perceiving them, which led to the creation of ideas of superiority and inferiority among them. Thus, it is important to reflect on how

6. "[...] a respeito da relação entre a emergência da linguística como campo de saber (FOUCAULT, 1979 , 2000) e o projeto colonial, em que a língua foi transformada em um objeto a ser escrutinado, classificado, nomeado, destrinchado, analisado e descrito segundo certas regras que definem o que conta como verdadeiro dentro dos limites de um dado regime discursivo." 
language has been understood throughout time, especially since Saussure (2011 [1916]), as the application of a common epistemological model, grounded on a European viewpoint, was set to all phenomena, disregarding the history of local singularities. For Severo (2017), such modern/colonial stance is a reductivizing, universalizing, generalizing and essentializing one, which does not only overlook the diversity of language practices, but also downplays it. Consequently, because of its influence, even nowadays, discursive regimes that reinforce such ideas are still being reproduced and certain power relations, influenced by them, are still being endorsed.

Saussure's book entitled Course in General Linguistics, first published in 1916, was the founding work that established linguistics as a modern science. From it, assumptions about language were made, based on specific western perspectives. For Pennycook (2018b), the epitome of this model is the Saussurean talking beads. See figure 1.

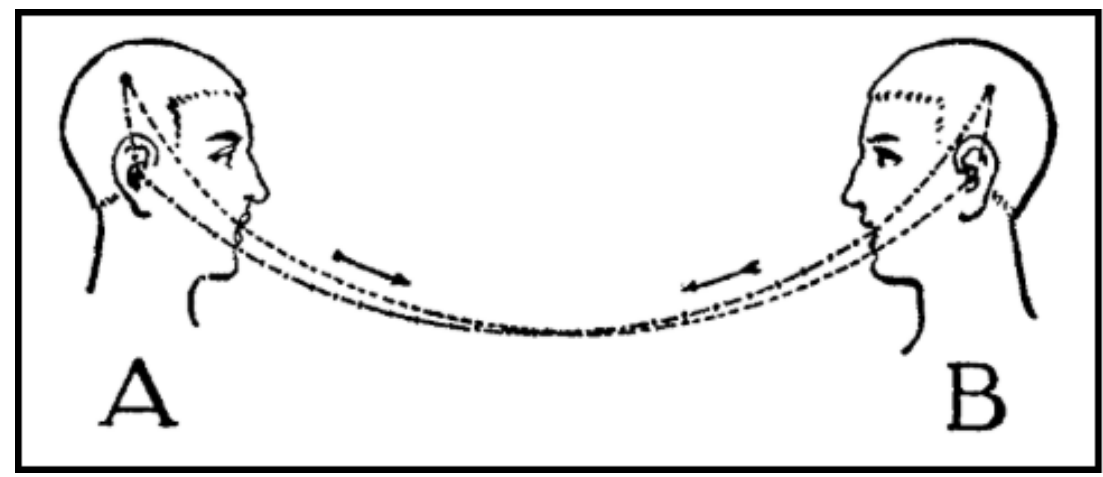

Figure 1. Speaking-circuit

Source: Saussure (2011, p. 11).

Both decolonial and posthumanist scholars criticize Saussure's (2011) speaking circuit, as well as what it entails. Pratt (2012), Fabrício (2017) and Nascimento (2017) highlight the absence of specific identities and the display of others: the subjects in the figure are western, white, male, young, and there are no marks of belonging (like class and religion); their appearance is identical and, therefore, there are no relations of power involved; there is no context; and their communication happens in an identical and completely symmetrical way. Pratts (2012) underscores that modern linguistics was grounded on such perspectives, which brought about specific understandings about language and communication. As a result, "[...] conceptions and practices of language were forged as part of the 
colonial project, having as a privileged perspective the geopolitical position and interests of the colonizer"7 (NASCIMENTO, 2017, p. 64, our translation). This notion of language thereby created new forms of exclusion, which encompassed not only the processes and elements related to language itself, but also to the people involved in them.

Fabrício (2017, p. 31, our translation) adds that seeing language as a mediating tool between the internal (individual) and external (the outside world) domains is a reductionist perspective, which encourages ideas such as transmissionreception, linear codification-decodification of meanings and underlying stability for communication $-\mathrm{a}$ "[ $[\ldots]$ belief that creates a perception of language whose historical and contextual insensitivity constitutes it as operations which are exclusively mental, cognitive, disembodied, and separate from society. ${ }^{\prime \prime}$ The author emphasizes the inadequacy of this model, which is based on colonial modernity and creates linguistic ideologies that need to be questioned, disinvested, deconstructed and reimagined.

According to Braidotti (2016), Cook (2016) and Papadopoulos (2018), posthumanism provides critiques of social aspects with regard to social injustices, like decoloniality does. However, as Patel (2016) and Murris (2016) argue, concerning decoloniality and posthumanism, respectively, both projects also open up a space for a notion of justice that includes but goes beyond social justice. This is related to an emerging understanding of how we are entangled with matter, space and nonhuman others.

Posthumanist applied linguistics criticizes structural linguistics for perceiving language as a system located in individual minds, having one person's brain as the starting point for the speech circuit, sustained by the premise that one human being can perfectly understand another (PENNYCOOK, 2018b; TOOHEY, 2018a). As Pennycook (2018b) underlines, the notion of isolated heads passing messages back and forth, encoding and decoding ideas, based on the presumption of mutual understanding, is woefully inadequate for a comprehension of communication. In his words,

[w] hat this [Saussure's model of talking heads] is missing is the context of communication, the messiness of communication, the conflict, ambiguity and uncertainty of communication, the role of bodies, places, artefacts, clothes, feelings, smells, social relations, gender, race,

7. "[...] concepções e práticas de linguagem hegemônicas foram forjadas como parte do projeto colonial, tendo como perspectiva privilegiada a posição geopolítica e os interesses do colonizador."

8. "[...] crença formadora de uma percepção de língua/linguagem cuja insensibilidade histórica e contextual as constituem como operações exclusivamente mentais, cognitivas, descorporificadas e apartadas da sociedade." 
class and so much more. Indeed, it is missing almost everything. (PENNYCOOK, 2018b, p. 93).

In the same vein, Canagarajah (2017, p. 33) states that the Saussurean conception of language tends to favor "[...] homogeneity, normativity, and control. Structures are abstracted from the messiness of material life and social practice. In making structures fundamental and generative, structuralism imposes order and control over material life." However, despite arguments such as Canagarajah's (2017) and Pennycook's (2018b), which date back at least to 1980s, with Harris's (1981, 1990) work, Saussure's model still has a considerable influence on current understandings of language and communication, firmly grounded on humanist perceptions. This colonial and humanist project focused on the idea of language taking place exclusively between human heads, and that entailed the disregard of people's bodies and senses.

Following this line of thought, Pennycook (2018b, p. 79-80) argues we need to problematize "[...] the constant reiteration of the point that it is language that separates humans from other animals." This is still a very strong assertion reinforced by traditional applied linguistics. According to the author,

[t]his argument has several consequences: it insists on human exceptionality, which then requires an account of an evolutionary leap in human communication (rather than a more gradualist evolution from gesture to language). It therefore focuses on those features of human language which appear distinctive, ignoring the bigger picture of gesture, nonverbal communication or other sensory domains. (PENNYCOOK, 2018b, p. 81).

By considering such arguments, Pennycook (2018b) adds that Chomsky's $(1986,2000)$ position is that of radical discontinuity, as it considers that only humans have language, based on what Pennycook (2018b) calls saltationary theories (from Latin saltus, jump), which disregard the gradual development from body expressions to what we currently understand as language. As generativists tried to grasp the evolution of the human mind, they associated it to Cartesian rationalism, reinforcing a separation between body and mind, or as Canagarajah (2017, p. 33) puts it, "the bias of mind over matter".

As Hymes (1971, as cited in CANAGARAJAH, 2017, p. 32) observes, "Chomsky [(n.d.)] took structuralism further in a cognitive and individualized direction." According to Pennycook (2018b, p. 81), Berwick and Chomsky's (2016) position promotes the understanding of language as a universal and asocial system that is "internalized, formalized and grammaticalized", and located in the brain. Such comprehension of language and its relation to the world is too narrow, as it completely overlooks language's entangled relations to the material world. 
Deleuze and Guattari (2005) affirm, and De Freitas and Curinga (2015) reiterate, that Chomskian linguistics fails to locate language in the material context from where it emerges. Pennycook (2018b, p. 104) endorses that "[i]t is these Western humanist assumptions about thought and language that the decolonial option starts to question."

Concerning more recent frameworks adopted in the field, Toohey (2018b) addresses the contributions of sociocultural and poststructuralist theories to the analyses of language and identity in applied linguistics. As she highlights, unlike structuralist and generativist perspectives, these frameworks reject binaries such as self/society, and recognize that individuals are always situated in social relations of power with others. However, she states that their primary focus is on human interactions, "[...] with the non-human usually seen as context and/or mediations for human activity" (KIRSCHNER, MARTIN, 2010, as cited in TOOHEY, 2018b, p. 4). From a posthumanist perspective, materiality is seen as more than a stage on which humans perform (MACLURE, 2013; TOOHEY, 2018b), that is, it is more than simply a background, insofar as posthumanism refuses to perceive humans as the center, and rather considers them as part of assemblages, seeking to conceive all (human and nonhuman) entities in a more horizontal plane. In the following section we return to this specific discussion in more detail.

\section{LANGUAGE FROM A POSTHUMANIST PERSPECTIVE}

Posthumanism directly challenges traditional theories of language (SMYTHE et al., 2017). For Pennycook (2018b), posthumanism can help us understand humans not as separate from the rest of the world, but rather as a part of it, as intertwined and entangled in it. That said, Latour (1999), Maclure (2013) and Pennycook (2018b) point out that this praxiological framework thereby also questions where thought and language occur and what role a supposedly exterior world plays. As the latter sees it, "[...] there is no longer a world 'out there' separate from humans and represented in language but rather a dynamic interrelationship between different materialities" (PENNYCOOK, 2018a, p. 449, quotation marks in original). In this sense, the material world is constantly intra-acting with our cognition. In the same vein, Clark (2008, p. 219) claims that, according to this perspective, the human mind "[...] emerges as the productive interface of brain, body, and social and material world." In Pennycook's words (2018b, p. 15),

[w] hile extended cognition points to the ways we outsource our thinking [...] to other systems, such as mobile phones, distributed cognition focuses on the ways in which our 
thinking involves the environment about us. Questioning the distinction between internal (the brain) and external (our surrounds) domains, this line of thought poses serious questions for the notion of where the human starts and ends. [...] [L]anguage can equally be seen as distributed in space. This takes us beyond a discussion of language in the brain, in society or in context and urges us to think about language in alternative spatial and material terms.

As a result, language is decentralized and let down from its superior position. The point here is not to undermine the fact that human language is highly complex and multifaceted, but rather to provincialize it: "[...] to recognize its limits, to acknowledge its constructedness, and to open up to a world of communicating and knowing beyond - or beside/s words" (THURLOW, 2016, p. 503). Thus, languages are considered elements that are present in assemblages, in which entities and forces affect and are affected by each other (intra-act), as discursive and material relations are intertwined across space. Therefore, in a few words, language and cognition are "[...] on the one hand embodied, embedded and enacted (far more than representational activity in the mind) and, on the other hand, extended, distributed and situated (involving the world outside the head)" (STEFFENSEN, 2012, as cited in PENNYCOOK, 2018b, p. 52). In addition, taking into account that, from this perspective, there is no inside and outside, and that language and agency are distributed across people, places and artefacts, playing active roles in the world (PENNYCOOK, 2018b, 2019), Canagarajah (2017) claims that we need to also understand the meaning-making ability as distributed, since social networks, things and bodies work in entangled ways.

By considering a spatial orientation, Canagarajah (2017) sees space as active, generative and agentive. In this sense, human beings, nonhuman others and space shape and co-construct each other in assemblages. Likewise, language is conceived as part of a broader set of semiotic possibilities, and the material world is perceived as having agency in the process. In their studies regarding spatial repertoires, Canagarajah (2017) and Pennycook (2018a, 2018b) advocate for an understanding of them as distributed in entanglements that encompass social practices and material embodiment; thus, things become materially and discursively intertwined.

Language use is thereby seen as part of assemblages (SMYTHE et al., 2017) - "[...] a coming together of people, languages, places and objects [...] [that] provide[s] a particular set of semiotic possibilities" (PENNYCOOK, 2018b, p. 99). In the posthumanist framework of languages as semiotic assemblages, Pennycook (2018b) suggests the ideas of alignment and attunement, instead of mutual intelligibility, rejecting the view of Saussure's ideal model of communication. According to the author, what happens in communication are attempts by the speakers to flexibly adapt to each other's speeches, so they can try to reach some 
form of understanding, which is always constituted by conflicts, negotiations and adjustments. As we see it, we are not fully able to verbalize what happens in our mental processes; consequently, what we say is just a fragmented part of what we mentally experience. Therefore, what the communicative process involves is much more complex because if we do not match our own thoughts with our words, it seems naïve to think we can match other people's. In this line of thought, Canagarajah (2017, p. 49) claims that

[f]rom a spatial orientation, communicative proficiency involves the ability to align diverse semiotic and spatial resources for successful activity. Along with the flat ontology of assemblage, it holds that [...] beyond giving primacy to the mind, it posits that the body and material objects facilitate thinking.

The author shares some examples, from studies he carried out, of how nonverbal resources do not simply aid people with thinking and talking, but rather mediate and shape their mental processes and language use, meanings and understandings. Therefore, as Toohey (2018b) states, in this perspective, tools do not merely mediate interactions and actions, but rather intra-act with humans, as they are also perceived as active and changing parts of assemblages. Grounded on this viewpoint, linguistic and nonlinguistic resources are intertwined in such a way that it is possible to note a kind of distributed agency among them, just as there is an entanglement between human and non-human agencies (APPLEBY; PENNYCOOK, 2017; BENNETT, 2010). Accordingly, based on Lenz Taguchi's (2010) arguments, Murris (2016) claims that there is a performative agency, insofar as nonhuman entities have a certain force and power that can transform our thoughts and our being.

Furthermore, by taking discussions such as the ones addressed here into consideration, MacLure (2013, p. 663-664) argues that

[we] need to find ways of researching and thinking that are able to engage more fully with the materiality of language itself - the fact that language is in and of the body; always issuing from the body; being impeded by the body; affecting other bodies. Yet also, of course, always leaving the body, becoming immaterial, ideational, representational, a striated, collective, cultural and symbolic resource.

Following Maclure's ideas (2013), De Freitas and Curinga (2015, p. 249) argue that we need " $[\ldots]$ to study the imbrication (intricate interlocking) of matter and meaning in new ways." Similarly, Deleuze and Guattari (2005) declare that language should be considered a form of material expression. In this line of thought, Rotman (2008, as cited in DE FREITAS; CURINGA, 2015, p. 257) claims that, for example, 
[...] talking involves the curling of a tongue and various minute vibratory actions of the face and body. [...] [As] the evolutionary neurologist Terrence Deacon [(n.d.) argues], [...] one listens to the movements of these body parts as one makes sense of what another is saying. Listening is thus a complex material engagement at the molecular level, beneath the level of a sonic unit of meaning, where one absorbs the pauses, accelerations, fallings away and other bodily performances that produce the sounds.

The author's example is one of the ways we can perceive the materiality of language, its dynamic entanglement with our bodies and our surroundings. In this sense, things work as extensions of each other, distributed across space. As a result, following this perspective, the dichotomy between discourse and materiality is deconstructed (APPLEBY; PENNYCOOK, 2017; MACLURE, 2013; PENNYCOOK, 2018a, 2018b; TOOHEY, 2018a, 2018b). Thus, as Barad (2003, 2007), Maclure (2013) and Murris (2016) argue, we need to think, instead, in terms of materialist-discursive assemblages/entanglements. For Barad (2003, 2007), our bodies exist through material and discursive relations, and De Freitas and Curinga $(2015$, p. 263$)$ add that this reconfiguration encourages new understandings "[...] to think past the usual confines of the individual."

On the other hand, according to Toohey (2018a, p. 37, quotation marks in original), it is important to underline the concept of agential cuts, introduced by Barad (2007), "[...] as a way to signal that in research (and life) we make boundaries between objects and activities, but that 'cuts' could always be made in other ways." In this sense, Toohey $(2018 \mathrm{a}$, p. 39$)$ claims that, as posthumanism adopts a flat ontology, we need to be aware that when we use the linguistic concept of language, we make "[...] an agential cut which abstracts language (and its users) from events, ignoring its becoming and its entanglement with the becomings of its human and non-human companions." This poses methodological and analytical questions to the work we develop. For Canagarajah (2017), these pragmatic boundaries (or cuts) are the options we make when we define our unit and focus of analysis from assemblages, but he states that, although we make specific choices, we cannot disregard their relation to the whole. Last but not least, we add that it is of paramount importance to take into account ethical demands of the contexts with which we are involved when we make cuts.

\section{FINAL REMARKS}

As Pennycook (2018b, 2019) argues, a posthumanist framework encompasses ideas from many different fields, ideas that sometimes are not obviously tied to posthumanism, like Indigenous knowledges and decolonial thoughts. Nonetheless, 
this praxiological perspective "[...] has made it possible to pull together a range of interconnected ideas under one roof and to explore this emerging landscape that repositions people, places and objects in a new configuration" (PENNYCOOK, 2018b, p. 131). As we state in the first section, we consider that inter-epistemic dialogues (NASCIMENTO, 2017) can substantially contribute to the development of new ethico-onto-epistemological viewpoints beyond human hubris, in order to perceive human beings and nonhuman others in a more horizontal plane.

As both decolonial and posthumanist perspectives embrace social aspects and the materiality that constitutes us, our surroundings and nonhuman others, in entangled ways (CANAGARAJAH, 2017; PATEL, 2016; PENNYCOOK, 2018b), from our viewpoint, they articulate ideas that are meaningful and useful for the work we develop, insofar as they have helped us to better understand and reflect on what we do and on how we could do things differently in our contexts. For instance, we have perceived the need to decenter the subject of language education and teacher education, considering $\mathrm{s} / \mathrm{he}$ should be seen as one of the elements that integrates (educational) assemblages, in which other entities are present as well, such as the classroom/space, teaching materials, objects, teaching aids, other students, the teacher/professor etc. In this line of thought, the materiality that surrounds us can be conceived as extensions of ourselves in both material and discursive terms, like the board and the textbook for the teacher.

Therefore, as applied linguists, inspired by decoloniality and posthumanism, we advocate for a more expansive understanding of language and our relations to it. By comprehending what we do based on other perspectives, we can develop new ways of thinking and becoming which may help us in the process of delinking from exclusionary narratives posed by humanism and coloniality.

\section{REFERENCES}

APPLEBY, R.; PENNYCOOK, A. (2017). Swimming with sharks, ecological feminism and posthuman language politics. Critical Inquiry in Language Studies, v. 14, n. 2-3, pp. 239-261.

BARAD, K. (2003). Posthumanist performativity: toward an understanding of how matter comes to matter. Signs: Journal of Women in Culture and Society, v. 28, n. 3, pp. 801-831.

BARAD, K. (2007). Meeting the universe balfway: quantum physics and the entanglement of matter and meaning. Durham, NC: Duke University Press. 
BENNETT, J. (2010). Vibrant matter: a political ecology of things. Durham, NC: Duke University Press.

BERWICK, R.; CHOMSKY, N. (2016). Why only us? Language and evolution. Cambridge: MIT Press.

BORELLI, J. D. V. P.; PESSOA, R. R. (2019). O estágio e o desafio decolonial: problematizações sobre as relações interpessoais de seus/suas agentes. MOARA, n. 51, pp. 75-96.

BRAIDOTTI, R. (2013). The Posthuman. Cambridge, UK: Polity Press, 2013.

BRAIDOTTI, R. (2016). Posthuman critical theory. In: BANERJI, D.; PARANJAPE, M. (Ed.). Critical posthumanism and planetary futures. New Dheli: Springer, pp. 13-32.

BRAIDOTTI, R. (2017). Posthuman critical theory. Journal of Posthuman Studies, v. 1, n. 1, pp. 9-25.

CANAGARAJAH, S. (2017). Translingual practice as spatial repertoires: expanding the paradigm beyond structuralist orientations. Applied Linguistics, v. 39, n. 1, pp. 31-54.

CHOMSKY, N. (1986). Knowledge of language: its nature, origins and use. Westport, CT: Praeger.

CHOMSKY, N. (2000). New horizons in the study of language and mind. Cambridge: Cambridge University Press.

CLARK, A. (2008). Supersizing the mind: embodiment, action, and cognitive extension. Oxford: Oxford University Press.

COOK, J. P. (2016). The posthuman curriculum and the teacher. 2016. 204f. Doctoral dissertation (Education in Curriculum Studies) - Jack N. Averitt College of Graduate Studies (COGS), Georgia Southern University, Statesboro, Georgia.

COOLE, D.; FROST, S. (2010). Introducing the new materialisms. In: COOLE, D.; FROST, S. (Ed.). New materialisms: ontology, agency and politics. Durham and London: Duke University Press, pp. 1-43.

DE FREITAS, E.; CURINGA, M. (2015). New materialist approaches to the study of language and identity: assembling the posthuman subject. Curriculum Inquiry, v. 45, n. 3 , pp. $249-265$. 
DELEUZE, G.; GUATTARI, F. (2005) A thousand plateaus: capitalism and schizophrenia. Trans. by Brian Massumi. Minneapolis: University of Minnesota Press.

FABRÍCIO, B. F. (2017). Processos de ensino-aprendizagem, educação linguística e decolonialidade. In: ZOLIN-VESZ, F. (Org.). Linguagens e descolonialidades: práticas linguageiras e produção de (des)colonialidade no mundo contemporâneo. Campinas, SP: Pontes, v. 2, pp. 15-38.

FERRANDO, F. (2013). Posthumanism, transhumanism, antihumanism, metahumanism, and new materialisms: differences and relations. Existenz: an International Journal in Philosophy, Religion, Politics, and the Arts, v. 8, n. 2, pp. 26-32.

FOUCAULT, M. (1979). Microfísica do poder. Rio de Janeiro: Edições Graal.

FOUCAULT, M. (2000). As palavras e as coisas. $8^{\text {th }}$ ed. Tran. Salma Tannus Muchail. São Paulo: Martins Fontes.

FOUCAULT, M. (2008). A arqueologia do saber. $7^{\text {th }}$ ed. Tran. Luiz Felipe Baeta Neves. Rio de Janeiro: Forense Universitária.

GILLIGAN, C. (1982). In a different voice: psychological theory and women's development. Cambridge, London: Harvard University Press.

GROSFOGUEL, R. (2010). Para descolonizar os estudos de economia política e os estudos pós-coloniais: transmodernidade, pensamento de fronteira e colonialidade global. In: SOUSA SANTOS, B.; MENESES, M. P. (Org.). Epistemologias do Sul. São Paulo: Cortez, pp. 455-491.

HARAWAY, D. (2008). When species meet. Minneapolis, MN: Minnesota University Press.

HARAWAY, D. (2016). Staying with the trouble: making kin in the Chthulucene. Durham: Duke University Press.

HARRIS, R. (1981). The language myth. London: Duckworth.

HARRIS, R. (1990). On redefining linguistics. In: DAVIS, H.; TAYLOR, T. (Ed.). Redefining linguistics. London: Routledge, pp. 18-52.

HYMES, D. (1971). On linguistic theory, communicative competence, and the education of disadvantaged children. In: WAX, M. L.; DIAMOND, S. A.; GEARING, F. (Ed.). Antbropological perspectives on education. New York: Basic Books, pp. 51-66. 
KERNER, I. (2018). Interrogating western modernity: postcolonial reflections on occidental claims and action. Cadernos de Filosofia Alemã: Crítica e Modernidade, v. 23, n. 2, pp. 35-52.

KIRSCHNER, S.; MARTIN, J. M. (2010). The sociocultural turn in psychology: the contextual emergence of mind and self. In: KIRSCHNER, S.; MARTIN, J. M. (Ed.). The sociocultural turn in psychology: the contextual emergence of mind and self. New York: Columbia University Press, pp. 1-28.

LARRABEE, M. J. (1993). An etbic of care: feminist and interdisciplinary perspectives. London, New York: Routledge.

LATOUR, B. (1999). Pandora's hope: essays on the reality of science studies. Cambridge: Harvard University Press.

LATOUR, B. (2004). Politics of nature: how to bring the sciences into democracy. Cambridge, MA: Harvard University Press.

LENZ TAGUCHI, H. (2010). Going beyond the theory/practice divide in early childhood education. London: Routledge Contesting Early Childhood Series.

LES CONVIVIALISTES. (2014). Convivialist manifesto: a declaration of interdependence (Global Dialogues 3). Trans. Margaret Clarke. Duisburg: Käte Hamburger Kolleg/ Centre for Global Cooperation Research (KHK/GCR21).

MACLURE, M. (2013). Researching without representation? Language and materiality in post-qualitative methodology. International Journal of Qualitative Studies in Education, v. 26, n. 6, pp. 658-667.

MALDONADO-TORRES, N. (2007). Sobre la colonialidad del ser: contribuciones al desarrollo de un concepto. In: CASTRO-GÓMEZ, S.; GROFÓGUEL, R. (Org.). El giro decolonial: reflexiones para uma diversidad epistémica más allá del capitalismo global. Bogotá: Siglo del Hombre Editores, pp. 127-167.

MARTIN, K.; MIRRABOOPA, B. (2003). Ways of knowing, being and doing: a theoretical framework and methods for Indigenous and Indigenist research. Journal of Australian Studies, v. 27, n. 76, pp. 203-214.

MASTRELLA-DE-ANDRADE, M. R.; PESSOA, R. R. (2019). A critical, decolonial glance at language teacher education in Brazil: on being prepared to teach. DELTA Documentação de Estudos em Linguística Teórica e Aplicada, v. 35, n. 3, pp. 1-28. 
MIGNOLO, W. (2000). Local bistories/global designs: coloniality, subaltern knowledges, and border thinking. Princeton, NJ: Princeton University Press.

MIGNOLO, W. (2007). Delinking. Cultural Studies, v. 21, n. 2-3, pp. 449-514.

MIGNOLO, W. (2011). The darker side of western modernity: global futures, decolonial options. Durham: Duke University Press.

MIGNOLO, W. (2018a). What does it mean to decolonize? In: WALSH, C. E.; MIGNOLO, W. D. On decoloniality: concepts, analytics, praxis. Durham and London: Duke University Press, pp. 105-134.

MIGNOLO, W. (2018b). The invention of the buman and the three pillars of the colonial matrix of power. In: WALSH, C. E.; MIGNOLO, W. On decoloniality: concepts, analytics, praxis. Durham and London: Duke University Press, pp. 153-176.

MIGNOLO, W.; VÁZQUEZ, R. (2017). Pedagogía y (de)colonialidad. In: WALSH, C. (Ed.). Pedagogías decoloniales: prácticas insurgentes de resistir, (re)existir y (re)vivir. Educador, Quito: Abya-Yala, Tomo II, pp. 489-508.

MURRIS, K. (2016). Rhodes must fall: a posthumanist orientation to decolonising higher education institutions. South African Journal of Higher Education, v. 30, n. 3, pp. 274-294.

NASCIMENTO, A. M. do. (2017). A queda do céu: elementos para a descentralização epistemológica dos estudos da linguagem desde visões indígenas. In: ZOLINVESZ, F. (Org.). Linguagens e descolonialidades: práticas linguageiras e produção de (des) colonialidade no mundo contemporâneo. Vol. 2. Campinas, SP: Pontes, pp. 55-78.

NASCIMENTO, A. M. do. (2019). Pesquisas decoloniais na educação e na análise do discurso crítica. Presented at II Jornada Internacional de Linguística Aplicada Crítica (II JILAC). Universidade de Brasília (UnB), Brasília, July 23-25, 2019.

PAPADOPOULOS, D. (2018). Insurgent posthumanism. In: BRAIDOTTI, R.; HLAVAJOVA, M. (Ed.). Posthuman glossary. London and New York: Bloomsbury Academic, pp. 204-207.

PATEL, L. (2016). Decolonizing educational research: from ownership to answerability. New York: Routledge.

PENNYCOOK, A. (2018a). Posthumanist applied linguistics. Applied Linguistics, v. 39, n. 4, pp. 445-461. 
PENNYCOOK, A. (2018b). Posthumanist applied linguistics. Oxford and New York: Routledge.

PENNYCOOK, A. (2019). Posthumanist applied linguistics. Presented at $V$ Jornada de Educação, Linguagem e Tecnologia (V JELT). Universidade Estadual de Campinas (Unicamp), São Paulo, May 30-31, 2019.

PESSOA, R. R. (2019). Formação de professores/as em tempos críticos: reflexões sobre colonialidades e busca por um pensar decolonial. In: MAGNO E SILVA, W. A. G. P.; SILVA, W. R.; CAMPOS, D. M. (Org.). Desafios da formação de professores na Linguística Aplicada. 1ed. Campinas, SP: Pontes, pp. 173-186.

PESSOA, R. R.; BORELLI, J. D. V. P.; SILVESTRE, V. P. V. (2018). "Speaking properly": language conceptions problematized in English lessons of an undergraduate teacher education course in Brazil. Ilha do Desterro, v. 71, n. 3, pp. 81-98.

PESSOA, R. R.; SILVESTRE, V. P. V.; BORELLI, J. D. V. P. (2019). Challenges of a decolonial undertaking in teacher education. Calidoscópio, v. 17, n. 2, pp. 342-360.

PRATT, M. L. (2012). "If English was good enough for Jesus...": monolinguismo y mala fe. Critical Multilingualism Studies, v. 1, n. 1, pp. 12-30.

QUIJANO, A. (2000). The coloniality of power and social classification. Journal of worldsystems research, v. 6, n. 2, pp. 342-386.

QUIJANO, A. (2005). Colonialidade do poder, eurocentrismo e América Latina. In: LANDER, E. (Org.). A colonialidade do saber: eurocentrismo e ciências sociais. Buenos Aires: Conselho Latino-americano de Ciências Sociais - CLASCO, pp. 107-130.

ROTMAN, B. (2008). 2008 virtual X and ghost effects. Presented at Landscapes and politics of new media. University of Aberdeen, Scotland, UK.

SANTOS, B. de S. (2010). Descolonizar el saber, reionetar el poder. Montevidéu: Ediciones Trilce.

SAUSSURE, F. de. (2011). Course in general linguistics. Trans. Wade Baskin. New York: Columbia University Press, 1916.

SEVERO, C. G. (2017). Pós-colonialismo e linguística: relação impossível? In: ZOLINVESZ, F. (Org.). Linguagens e descolonialidades: práticas linguageiras e produção de (des) colonialidade no mundo contemporâneo. Vol. 2. Campinas, SP: Pontes, pp. 39-54. 
SMYTHE, S. et al. (2017). Materiality and language learning in classrooms. In: SMYTHE, S. et al. Disrupting boundaries in education and research. Cambridge: Cambridge University Press, pp. 34-58.

SOUSA, L. P. de Q. (2017). Critical collaborative posthumanist teacher education: deconstructions and reconstructions of the English language teaching-learning process. In: IX Seminário de Línguas Estrangeiras: A Internacionalização da Educação Superior e o Papel das Línguas Estrangeiras, 2017, Goiânia. Programação e Resumos. Goiânia: Departamento de Línguas Estrangeiras, Faculdade de Letras, UFG, pp. 61-62.

SOUSA, L. P. de Q. (2018). Formação docente colaborativa pós-humanista crítica: desconstruções e reconstruções do processo ensino-aprendizagem de língua inglesa. In: IX Seminário de Línguas Estrangeiras, 2018, Goiânia. Anais do IX Seminário de Linguas Estrangeiras. Goiânia: CEGRAF/UFG, pp. 318-341.

SOUSA, L. P. de Q. (2019a). Pennycook, A. (2018). Posthumanist applied linguistics. Oxford and New York: Routledge. Colombian Applied Linguistics Journal, v. 21, n. 1, pp. 139-142.

SOUSA, L. P. de Q. (2019b). Perspectivas pós-humanistas na formação docente e no ensino de língua inglesa. Presented at $V$ Jornada de Educação, Linguagem e Tecnologia ( $V$ JELT). Universidade Estadual de Campinas (Unicamp), São Paulo, May 30-31, 2019.

SOUSA, L. P. de Q. (2019c). Uma perspectiva pós-humanista sobre formação docente e ensino-aprendizagem de língua inglesa. Presented at II Jornada Internacional de Linguística Aplicada Crítica (II JILAC). Universidade de Brasília (UnB), Brasília, July 23-25, 2019.

STEFFENSEN, S. V. (2012). Beyond mind: an extended ecology of languaging. In: COWLEY, S. (Ed.). Distributed language. Amsterdam: John Benjamins, pp. 185-210.

THURLOW, C. (2016). Queering critical discourse studies and/or performing "post-class" ideologies. Critical Discourse Studies, v. 13, n. 5, pp. 485-514.

TOOHEY, K. (2018a). Learning English at school: identity, social-material relations and classroom practice, $2^{\text {nd }}$ ed. Bristol; Blue Ridge Summit: Multilingual Matters.

TOOHEY, K. (2018b). The onto-epistemologies of new materialism: implications for applied linguistics pedagogies and research. Applied Linguistics. Available at: https:// doi.org/10.1093/applin/amy046. Access on: May $22^{\text {nd }} 2019$. 
VERONELLI, G. (2015). The coloniality of language: race, expressivity, power and the darker side of modernity. Wagadu, v. 13, pp. 108-134.

VERONELLI, G. (2019). Perspectivas decoloniais na educação linguística e na formação docente. Presented at II Jornada Internacional de Linguística Aplicada Crítica (II JILAC). Universidade de Brasília (UnB), Brasília, July 23-25, 2019.

WALSH, C. E.; MIGNOLO, W. D. (2018). Introduction. In: WALSH, C. E.; MIGNOLO, W. D. On decoloniality: concepts, analytics, praxis. Durham and London: Duke University Press, pp. 1-12.

WINNUBST, S. (2018). Decolonial critique. In: BRAIDOTTI, R.; HLAVAJOVA, M. (Ed.). Postbuman glossary. London and New York: Bloomsbury Academic, pp. 97-99.

Recebido: 1/06/2019

Aceito: 15/07/2019

Publicado: 8/08/2019 